\title{
Privatisation, Decentralisation and Production Adjustment in the Russian Defence Industry
}

\author{
ANTONIO SÁNCHEZ-ANDRÉS
}

PRIVATISATION IN THE DEFenCe INDUSTRY was until 1993 characterised by two features. Firstly, it affected a small number of organisations considered not too important within the sector. Nevertheless, one must point out that, at the end of 1992, some outstanding companies from the defence sector started to be privatised, which marked the first extension of the phenomenon to this sector of the economy. Secondly, the privatisation in this early period lacked organisation and control. Legislation was passed in 1993 with the aim of establishing some order in the privatisation process in the defence industry. From that time (until 1996) the idea was to foster a broad privatisation process with a view to resolving the production problems suffered by the industry, at the same time facilitating reorganisation within defence companies, which would contribute to an increase in the volume of civilian production.

This article deals with the second phase of privatisation in the defence industry (from 1993). ${ }^{1}$ This period is characterised by a strong desire to push through broad privatisation in the sector. In particular, the article analyses the impact of privatisation and one of its major effects, decentralisation, on the adjustment of production in defence companies. First, we shall explain the dimensions of privatisation in this field and its impact on the transformation of production. Second, the main features of the decentralisation will be described, and in particular the creation of small companies within the defence sector. We shall examine the relationship between privatisation and decentralisation and analyse the impact of the creation of this new type of business on the adjustment process in the defence industry.

\section{The development of privatisation in the defence industr.}

In mid-1993 a Presidential Decree (no. 1267) ${ }^{2}$ was passed aiming at rationalising the privatisation of the defence industry. The decree divided the defence industry into three blocks: a group of organisations which were to remain in the hands of the state, a second group which would be privatised (but remain under the control of the state through the existence of controlling shares or a 'golden share'-a right of veto), and a third group which would be freely privatised. In addition, the managing boards and in particular the directors of the organisations were authorised to guide the privatisation of their companies through different measures; for instance, state interests were 
to be represented by the directors responsible for state-owned share packages, who could manage up to $20 \%$ of the total assets of the defence companies. The decree was completed at the end of the year with the publication of the list of companies and research centres that were not eligible for privatisation (449 organisations). The decree was to be in force for three years.

With the enactment of this decree, the privatisation of the defence industry was regulated to a greater extent than before and the decree affected not only which companies would be privatised but also the way it would take place. The initiative for privatisation was still in the hands of the companies themselves, although it was conditioned by the category of the organisation (defined by the controlling package of the state or the possession of a golden share). From this moment, the decision on the actual start of the privatisation process required the explicit approval of the government. The process would be implemented through inter-regional auctions.

The idea of the State Committee for the Management of the Defence Industry (Goskomoboronprom) was to develop privatisation in quite a controlled way. To that end, a group of organisations were set up ad hoc, for instance the company TOO Eko-Invest was created in January 1994. The founder was a defence industry institute from Moscow called AOOT Institut kompleksnykh problem svyazi (Ekos). This company acted as a broker and stock market consultant. It specialised in managing the privatisation process in defence companies. In particular, it was in charge of application of the rules established by the Russian Federal Property Fund regarding auctions of shares or privatisation vouchers, establishing selling places, etc. This company was financed by Goskomimushchestvo. The actual sale of shares was conducted by another organisation, Kassovyi Soyuz, also influenced by TOO EkoInvest. Goskomoboronprom helped in finding buyers for the shares offered. In the meantime, the organisations being privatised expressed their own preference as to who would buy their shares. In other words, a complex system was structured to allow the participation of the different institutions in the privatisation of the defence organisations, which ensured control over the privatisation of the sector.

At first the privatisation process developed slowly. However, in order to show that the privatisation of the defence industry was advancing, some typical companies in the sector were immediately transformed into share-based entities, for instance Irkutskoe proizvodstvennoe aviatsionnoe ob"edinenie (Irkutsk), Tul'skii oruzhennii zavod (Tula), or Nizhegorodskii mashinostroitel'nyi zavod (Nizhny Novgorod). But despite this willingness to foster privatisation, the process encountered numerous problems, including the stopping of privatisation in organisations where it had already started. ${ }^{3}$

In mid-1994 the mass sale of shares in the defence industry through voucher auctions was confirmed, although only in very few cases were the companies to be direct arms manufacturers. ${ }^{4}$ This process continued during the rest of the year. However, from 1995 the situation changed substantially and privatisation slowed down. Several problems were alleged to be the cause of the change.

(1) Poor economic situation and negative prospects in the companies. Although the technological, human and material level of the defence sector had been far superior to that of the rest of Russian industry, the use such economic resources 
in civilian production was thought to be very difficult or at least not profitable. The failure of the conversion process in Russia corroborated this idea. ${ }^{5}$ The drop in civilian and military production intensified the economic problems of the defence sector. This situation became clear when companies failed to meet their payments and even went into bankruptcy. Thus, the State Insolvency Committee declared that at the beginning of 1995 there were 203 defence industry organisations in a situation of bankruptcy. In fact. the firm AO Viton (St Petersburg), from the electronics sector, was officially declared bankrupt at the beginning of the same year.' In addition, privatisation proved not to have stimulated managers to carry out thorough restructuring in the companies. ${ }^{8}$ This situation led to serious doubts as regards the development of privatisation.

(2) Limited advantages of privatisation. First, the lack of good economic prospects caused the shares to be sold at relatively low prices. This was the case with $\mathrm{AO}$ Tekhpribor (St Petersburg) or Solnechnogorskii mekhanicheskii zavod (Solnechnogorsk, Moscow oblast'), both from the aviation sector (in particular, the latter is the only manufacturer of gliders). ${ }^{9}$ As a result, the companies were practically unable to obtain funding through the privatisation process. Second, the purchase of shares by companies' workforce-with few financial resources to invest in them-deprived them of the possibility of obtaining funds for production rehabilitation. And third, more than $80 \%$ of the shares sold were purchased by companies which did not foster investment in the defence companies, either because they did not want to do so or because they could not do so. ${ }^{10}$

(3) Limited participation by investors in the auctions. The result of privatisation was generally that the workforce acquired most of the shares (either for vouchers or for money). This is explained by the poor economic prospects, by Goskomoboronprom control over the privatisation process, and by investors' presumption of subsequent interference by the Defence Ministry in the business activity of the privatised companies. We must add that the managing boards of the companies and research centres systematically posed obstacles to the participation of external investors in general. 1 A typical example of such obstacles was to hold auctions on the premises of the company or research centre itself. To gain access to the organisations, a special permit was needed (and only staff were allowed to hold one); access was thus denied to external investors. ${ }^{12}$

(4) Loss of control over privatisation. Although the design of the privatisation process established tight control by Goskomoboronprom, such control was limited by the growing leadership of the managing boards of the defence organisations. In addition, the control exercised by both Goskomoboronprom and the managing boards weakened with the development of the privatisation process: growing difficulties were detected in identification of the private organisations participating in the auctions, and this situation worsened with the development of a secondary share market. This series of problems became more intense with the evolution of the privatisation process and recommendations were made not to rush the sale of shares in the defence industry, to avoid losing money. ${ }^{13}$ This attitude was defended in the Duma, and it was proposed that a special permit should be required to sell the shares. ${ }^{14}$ 
In mid-1995 the government attempted to re-launch privatisation in Russia through the transfer of state share packages (on deposit) to the banks, who would provide the state with loans. ${ }^{15}$ The relationship between this way of obtaining funds and privatisation is that-unofficially - the state was expected to be unable to repay the loans, and therefore the banks would become the owners of the shares; in other words, this is interpreted as a direct sale of shares to the banks which offered the loans. The importance of the decree for the defence industry is that three companies from the sector AO OKB im. Sukhogo (Moscow), AO Ulan-udenskoe aviatsionnoe PO (Ulan-Ude), and AO Arsen'evskaya aviatsionnaya kompaniya Progress (Arsen'evsk, Primorskii krai) were included in the list of companies which were to undergo such an experiment (the percentage of shares offered was $51 \%, 38 \%$ and $51 \%$ respectively). This financing mechanism opened the doors to the participation of large investors in the privatisation of defence companies, with the possibility of obtaining a share package big enough to offer significant decision-making capacity in a company. That is to say, this system questioned the control over privatisation in the defence industry exercised by both Goskomoboronprom and the managing boards of the companies.

As a result, a conflict arose regarding the system, which polarised around the case of AO OKB im. Sukhogo. The conflict became public through a letter sent by Goskomoboronprom and the Defence Ministry to the President. The first specific result was a reduction in the size of the share package in $A O O K B$ im Sukhogo from $51 \%$ to $24.5 \%$ of the initial capital of the organisation, thus preventing external agents from taking over control of the company. In addition, the participation of foreign investors in the auctions was forbidden. ${ }^{16}$ The second specific and final result was the exclusion of the defence organisations mentioned from the system of transfer of shares through deposil with a bank. ${ }^{17}$

In addition, companies in the defence sector managed to get special treatment. At the end of 1995 a special statute for defence organisations was confirmed: this allowed them to follow a special pace in the development of their privatisation, closely supervised by Goskomoboronprom. ${ }^{18}$ From this moment, new control devices were introduced in the privatisation of this type of industry. During the first half of 1996. Decree no. 541, dated 13 April 1996, ${ }^{19}$ and Governmental Disposition no. 802 , dated 12 July $1996{ }^{20}$ were passed. which can be interpreted as derogation of Decree no. 1267 , passed in 1993, and the legal ending of mass privatisation of the defence industry.

Decree no. 541 aims at reinforcing control over the different aspects of privatisation of the defence industry. Its implementation therefore affects both state and private companies. In this regard, the decree sets out the legal base for definition of the number and identity of both groups of organisations. The application of control over privatisation in the defence industry will be based on the creation of a special commission with full powers over this process. Goskomoboronprom has a strong influence on the commission: on the one hand, it enjoys explicit representation among the 2.3 members, and, on the other, Goskomoboronprom is considered to be the best technical consultant. These features became more evident with the transformation of Goskomoboronprom into the Ministry of the Defence Industry of the Russian Federation and the confirmation of the power of this new institution over the 
privatisation of defence organisations. ${ }^{21}$ The first task to be undertaken by the commission was the drawing up of a list-within 2 months of the passing of the decree-including all the defence organisations not eligible for privatisation, and those privatised ones where the state held shares or had participated. Governmental Disposition no. 802 then completed the decree by specifying 480 defence organisations not eligible for privatisation.

In fact, at the beginning of the privatisation phase when defence organisations started being included, around 300 such organisations had already initiated their privatisation process ( 78 in 1992, the rest in 1993), that is, $18 \%$ of the organisations managed by Goskomoboronprom. ${ }^{22}$ In 1994421 defence companies were privatised, and the total for 1995 was 442,23 i.e. $52 \%$ in two years. The general pattern was to permit half of the organisations to implement a free privatisation; the other half would be constrained by controlling packages or a golden share. ${ }^{24}$ The list of companies not eligible for privatisation was increased from 449 at the end of 1993 to 480 in 1996. Therefore, in mid-1996 the privatisation process in the defence sector had practically finished.

The privatisation of the defence industry even developed faster than expected in the plans of the second half of $1993 .^{25}$ This fact clarifies the doubts which initially arose regarding the privatisation of this strategic sector. However, an in-depth analysis of the way privatisation has taken place is still needed, and the development of the intensive phase of privatisation, that is, the visible contraction of the share packages in the hands of the state, the sale of the remaining shares (to be sold in the future), and the administrative detachment of Goskomoboronprom non-military organisations, are challenges which will arise in the new phase that started in 1997.

On the other hand, privatisation was initially considered to improve the economic situation of the companies. However, as the privatisation extended to a substantial part of the defence industry, the fall in production continued and even accelerated. In 1992 it was $82 \%$, in $199369 \%$, in $199445 \%$, in $199538 \%$ and in $199631 \%$ of the 1991 level. $^{26}$ Privatisation therefore failed to solve the production problems of the defence sector.

\section{Decentralisation and production adjustment}

Privatisation constituted an effective transfer of decision making to the companies. ${ }^{27}$ based on the reduction of central control over the privatised organisations and the strengthening of the decision-making capacity of their managers, legitimated by Decree 1267 of $1993 .^{28}$ In this context, although it did not solve the production problems of the firms or scientific centres, privatisation did foster the rise of decentralisation within the parent organisations. These decentralisations usually took the form of a small company created within the defence organisation. ${ }^{29}$ This type of decentralisation process represented the search for individualised solutions to the crisis suffered by the companies, ${ }^{30}$ and may therefore be a new device in the solution of the production problems of the defence sector. The question is whether spinningoff these small companies can contribute to solving the production problems of the parent companies. 


\section{Privatised companies}

Firstly, there is a series of cases where privatisation stimulated the break-up of defence companies along the lines of their former sub-division. In such cases, the decentralisation does not create small firms, although some examples can be found. A typical case of broad decentralisation is NPK Energiya (Voronezh), which promoted improvement of production and became a model of how to obtain positive results through company creation inside a defence organisation. However, we must point out that the organisational changes started in an experimental way at the end of the 1980s, and the defence organisations and decentralisation processes benefitted from special support. ${ }^{31}$

Another outstanding case is Arsenal (St Petersburg). This organisation had been restructured into private firms which covered the different production sections. Later on, the different companies re-grouped back into a holding company, but their internal reorganisation remained a peculiar one, as the design centre was left aside, in the hands of the state. In addition, within the group, small companies were set up with the objective of achieving more flexibility in production and a more diverse production specialisation. Despite the reorganisation, the overall production situation was not good, with poor results from efforts at conversion. ${ }^{32}$ In a similar manner, Kontsern Leninets (St Petersburg) was sub-divided into $26 \mathrm{firms}$, with different production profiles. Nevertheless, production ran into serious problems and mechanisms for recentralising it were developed. ${ }^{33}$ A more illustrative case is NPO Pozitron (St Petersburg). This company was in an acceptable condition as far as conversion was concerned, since the transfer of military resources to the civilian field took place at an early stage, initially achieving remarkable results. ${ }^{34}$ From the different sections of the defence organisation autonomous companies were created, developing new lines of civilian production and eliminating some of the traditional lines, which however caused the different activities to overlap in some cases. In other words, there were no co-ordination devices for the decentralised parts, and this damaged the viability of the new companies. ${ }^{35}$

Within this group, we must distinguish the cases in which a section becomes an autonomous company. Frequently, this reorganisation is justified by the necessity to separate civilian from military production. A typical example of this is the company AO Gorizont (Rostov on Don), which is considered to be a success. This company developed very far-reaching civilian/military separation, giving both types of activities a high degree of autonomy. It achieved relative stability of its level of production, thanks to the stabilisation of state military orders, its monopoly in the production of some ship equipment, the development of its former civilian production, and the good reception of these products by potential customers. ${ }^{36}$ This is a case where no essential production or technological changes were introduced, and there were no serious adaptation problems or need to search for new demand.

It is evident then that the decomposition of defence organisations into their different sections led to the generation of decentralisation processes without necessarily creating economically viable units. That is to say, the production problems of the parent organisations were not resolved, nor were those of the newly decentralised companies. In particular, this type of decentralisation (not too frequent) has the draw- 
back of breaking some informational or collaborative bonds, and may increase production distortions. For instance, the interrelationships between research and production centres may be disrupted. In order to solve these new problems, attempts to re-unify the decentralised sections may be made, but, given the deficient production conditions, the results have been debatable.

A more common phenomenon was the creation of small companies within defence organisations. Their presence was justified as a device to stimulate civilian production. either through conversion or diversification. Among examples of small company creation for traditional activities directly related to a defence organisation, we find NPO Saturn im. A. M. Lyul'ki (Moscow), which created the company Aldis for the promotion and sale of diesel engines, ${ }^{37}$ AO OKB im. Sukhogo, which created the company Peredovye tekhnologii Sukhogo for the sale of small aeroplanes, ${ }^{38}$ or Tomskii pribornyi zavod (Tomsk), where the small firm Konversiya ${ }^{39}$ was set up with the objective of promoting the production and sale of instruments with a civilian application. $^{40}$

However, in order to understand the nature of these cases better, it is worth mentioning two examples which explain the original idea which justified the rise of this kind of decentralisation. First, the case of the Moskovskii vertoletnyi zavod im. M. L. Milya (Moscow), where the company Legkie vertolety MI was created. This decentralisation occurred in 1986 with the objective of producing small helicopters, but it did not succeed owing to the lack of orders. With the spread of privatisation the company gained independence and became a private business. However, its new legal form was more orientated to procuring external funds than to improving production conditions. ${ }^{41}$ Second, in the Institute AO TsKB po sudam na podvodnykh kryl'yakh im. Alekseeva (Nizhny Novgorod) the company Inzhiniringovaya firma Transal was created with the objective of building ships, which were expected to be financed by a state order. ${ }^{42}$ The company was completely dependent on the production of one product only, which would only have been feasible if external funds were received.

These were cases that needed a certain amount of investment to start operations. However, the new company usually acts as a distributor of the product of the defence organisation. For this reason, its contribution to the production adjustment of the defence organisation is generally marginal. In addition, the capacity of the company to exist independently from the parent organisation is dubious and its survival often depends on the sale of one product only. In other words, this situation raises questions as to the ephemeral nature of these small companies (unless the necessary funds are obtained). On the other hand, this type of decentralisation leads to privatisation of the external revenue and at the same time it means the socialisation (transfer to the parent company) of at least part of the production costs.

In most of these cases, the technical conditions of production constrain a widespread rise of small companies. However, in some fields it is possible for these multiple decentralisations to take place without disrupting the initial profile of the defence organisation. One successful example of such industrial reorganisation is AO Svetlana (St Petersburg). Within the company the creation of small firms was encouraged in order to promote technical innovation. But we must point out that-owing to the special financial support received from the European Union for 
implementing their internal reorganisation - this can hardly be compared to other cases. ${ }^{+3}$ Another important example is AO Izhevskii radiozavod (Izhevsk), where specialised sections were created for the commercialisation of the company's production (marketing, distribution and sales), with the objective of overcoming the organisational deficiencies in adaptation to the new economic conditions. ${ }^{+4}$ In both cases, small companies acted as a support for the survival of the defence organisation.

However, the most common situation is where small companies develop new lines of production without a linkage with those traditionally manufactured in the defence organisation. These new lines of production are projects or products which can find a market in the economic conditions in Russia. For instance, in NPO Vektor (Ekaterinburg) 32 small firms were created which developed different conversion lines: production of telephones, medical instruments and agricultural equipment. ${ }^{45} \mathrm{~A}$ similar case is AO Polimer (Chapaevsk, Samara oblast'), where 14 small businesses were created for the development of conversion projects, in most cases unrelated to the company's main activity (perfumes, medicines, furniture, glass products). But since these companies do not receive funding, their existence is more or less formal. ${ }^{\text {th }}$ A common feature is that these companies only produce prototypes or very small series, owing to the lack of effective demand and funding. Their technical deficiencies prevent them from undertaking serial production of the goods offered. ${ }^{+7}$ That is, their future prospects are very limited.

It is also possible to find some small companies which have been successful from a production point of view. For example, AO Zavod Protsessor (Voronezh) created within itself TOO Raduga-Rossiya, which employs 100 people in the production of medical instruments. The formation of this company was possible thanks to a bank loan and the parallel creation of a marketing network which reduced the distance between the producer and the buycr. ${ }^{48}$ In this case, the necessity of finding initial funds to purchase equipment and machinery was overcome and at the same time solvent demand was found. A similar case is AO Samarskaya-Luka, created within the defence organisation AO Kinap (Samara), devoted to the production of equipment for the food industry. In this case, part of the resources were provided by the parent company, there was solvent demand because it was covering the food needs of the population, and the customers were all located within the same region. thus reducing marketing problems. However, other firms appeared whose success was doubtful. ${ }^{+9}$

Nevertheless, the case of the Kazanskoe OKB Soyuz institute may clarify the scope of the production success of the small companies formed within defence organisations. A decentralisation process took place in this institute with little overall success. Of the different companies created in it, only two ever really operated. The first was orientated to the manufacture of special equipment for the oil industry but-although there were good prospects for this line of business-funds were not found for the development of the project and therefore the company ceased production. Although the project was designed in the institute, one of the essential problems was the fact that the participation of other companies was required for serial production. This required large funds which did not exist. The second company produced cosmetics. In this case a foreign investor provided the funds which permitted the start of production. This company employs 40 people and sells its products in Russia. This 
example reveals a major problem, that is, the search for financing, as the companies have to purchase practically all the equipment to initiate their production, because of its sophistication. Another problem is that the defence organisations do not know what to produce (they lack information tools for getting to know what happens outside). If there is a foreign company, then the problems are overcome, althoughon the other hand-the projects may not find any demand because they are either too expensive or unnecessary-or fictitious. ${ }^{50}$

With the intensification of production problems in the defence companies, the traditional production activities were practically abandoned and new ones were developed by the small firms. That is to say, there was a tendency towards the disintegration of defence organisations into small companies. A successful example in production terms is Kachkanarskii radiozavod Formanta (Kachkanar, Sverdlovsk oblast') where 20 small companies were created for the production of commodities which represented most of the activities of the defence organisation. Seemingly, the situation of the organisation is stable partly thanks to the fact that these companies operate with regularity (producing televisions, vacuum cleaners, cassette-players, under a foreign licence). ${ }^{51}$ Another case where this phenomenon is also observed is Permskii mashinostroitel'nyi zavod im. V. I. Lenina (Perm'), where an intense process of small-company creation occurred (around 50 firms) but the companies reduced the production capacity of the defence organisation and only on very specific occasions were they viable economically. In particular, those which produced equipment for the oil and gas industries seemed to enjoy a good financial situation. ${ }^{52}$ their success was based to a great extent on the ease with which they could find customers, due to the profile of the company, and on the financial solvency of the demand, which permitted the company to acquire the necessary equipment. An additional element is that here there is no need to establish serial production; this means that better use can be made of the production heritage of the defence organisation.

However, far-reaching decentralisation achieved at the expense of the production capacity of the defence organisation frequently does not yield very positive results. A typical case is AO Sormovskii Lazur' (Nizhny Novgorod), where the traditional production (military and civilian) disappeared. A conversion process was implemented linked to the creation of small companies-a total of 13-with production profiles different from those of the parent company. ${ }^{53}$ In this case, the continued existence of the defence organisation is largely formal only. Zavod im. G. I. Petrovskogo (Nizhny Novgorod) is in a similar situation, and 15 small companies have been created with civilian production lines which have nothing to do with ship building, the activity of the parent company. ${ }^{54}$

In addition, in the cases with positive results, we must add that certain kinds of conduct have been observed which put in question the production activity of both the firms and the defence organisations. One example is the creation of the industrial company TOO Erad within the organisation Samarskoe Motorostroitel'noe PO (Samara). The former received orders from a company called Volzhskii filial NPO Energiya (Volzhskii, Samara oblast'), but, as a matter of fact, the work derived from an order placed by the defence organisation. Later, the profit made by TOO was shared by the management of both defence organisations. ${ }^{55}$ In the creation of this type of company. with a speculative nature, two models can be distinguished. First, the 
defence organisation receives a production order and then sub-contracts its production to its own small company, which in turn uses the production resources of the parent company. Then the product is sold and the profit goes to the small company. Indeed, this type of behaviour is found when the relevant production unit is the defence organisation, that is to say, when the order and financial flow come from the state (for instance, financial help from conversion programmes). Second, the small company may directly receive an order which will be met by the defence organisation, the profit being kept by the small company. This type of conduct is better explained by the Samara case. Therefore, the emergence of small companies appears to reduce the production of the defence organisation, and the tax paid is also lower. ${ }^{56}$

In contrast with industrial-orientated company creation, similar cases have been found in the commercial field. An illustration is Bashkirskoe elektrotekhnicheskoe ob"edinenie (Ufa). Within this organisation, the managing director created a commercial business called TOO Torgovyi dom BETO, in which he was a $90 \%$ shareholder. The small company acted as a sales division of the defence organisation, with the peculiarity that it did not have any expenses whatsoever, it held the monopoly of marketing the defence organisation's production and sold it at 5 to $25 \%$ higher prices. ${ }^{57}$ Indeed, these companies do not engage in production and their nature is strictly speculative. Their immediate effect is the extraction of resources from the defence organisations, without introducing production adjustments and without fostering any future prospects.

Such speculative behaviour has been taken into account by investors joining defence organisations. This is the case with the American firm Nick and $C$. Corporation which pursued an active policy of purchasing shares in Russian defence companies in the aviation field (in 1996 it had shares in 26 Russian companies). This corporation observed some small companies which were used by the directors to extract economic resources from the defence companies. ${ }^{58}$

Another example which questions the effectiveness of small companies is Novosibirskoe aviatsionnoe PO im. Chkalova (Novosibirsk). This company underwent an intensive internal decentralisation process with the objective of supplying its own employees with different goods. ${ }^{59}$ Such practices are increasing as a result of the absence of financial resources to pay the workers. Of course, this does not imply the development of any new production activities for either the defence organisation or the small companies, as they are mere passive survival devices.

\section{State-owned companies}

Decentralisation has also been observed in the state sector. One type of decentralisation refers to the decomposition of a company into its main sections. This is the case with NPO Orion (Moscow). This company underwent a generalised decentralisation in 1992, although the different parts of the company remained in the category of state companies. However, the result of the decentralisation was an important internal lack of co-ordination, which in turn caused a fall in production and scientific activity. Later a recentralisation occurred but, as the companies belonged to the state, the government re-integrated the different entities into branch unions (unitarnye dochernie). ${ }^{60}$ Another similar case, with features from both decentralisation through the decompo- 
sition of a company into its most relevant sections and from the creation of small companies, is NPO Polyus (Moscow). At the beginning of the 1990s the research centre and the serial production company became more independent from each other, but the results were not good and later the integration of the two sections was reinforced. At the same time, small companies were created with a view to stimulating innovation activities (20 companies). ${ }^{61}$ From this type of reorganisation we can assume the lack of positive results for the defence organisations.

However, the appearance of small companies within defence organisations has also been widespread. In the case of Voronezhskii mekhanicheskii zavod (Voronezh) conversion was actively promoted, in particular to produce equipment and machinery for the food and energy industries. In fact, the new production lines used 85-90\% of the equipment and technologies of the company. This process was based on far-reaching internal decentralisation. However, the company management did not succeed in co-ordinating the reorganisation. As a result, the traditional activities stopped and there were serious problems when trying to develop new ones. In particular, activities from the decentralised sections overlapped, major problems arose in production, and sales difficulties were not resolved. In order to overcome these problems, a series of activities were organised related to the production of equipment for the energy sector, as these had better economic prospects. ${ }^{62} \mathrm{~A}$ similar example is NPO Avtomatika (Ekaterinburg), where eight companies involved in conversion projects were created; however, only the small company AO Medavtomatika-which produces medical equipment-seemed to show positive results. Nevertheless, there have been problems with the financing and investment required to develop production. ${ }^{63}$

A more successful case is Safonovskii zavod plastmass PO Avangard (Safonovo, Smolensk oblast'), where the company Paton was constituted. This small company is developing a production line of the parent company (electrical capacitors) and has a major share of the Russian market for its products. In this case, we should mention that this small firm has benefited from the direct support of the defence organisation, which has allowed it to initiate serial production. As a result, the company enjoys a good economic situation. ${ }^{6+}$

On the other hand, in PO Uralgonzavod (Nizhny Tagil, Sverdlovsk oblast'), for instance, owing to the fall in production suffered by the defence organisation, some of its sections started producing strictly civilian goods and became independent companies. In particular, three companies were established (Ural'skii Vserossiikii tekhnologicheskii NII. Uralkriomash, and Ural'skii nauchno-tekhnologicheskii kompleks) within the defence organisation, and their results were good. In all three cases, the activities remained as before, or at least underwent very few changes. Their output normally consisted of non-standardised products. ${ }^{65}$

Decentralisation has progressively affected state-owned organisations, although this is quite a recent process. The creation of small companies in state defence organisations is spreading, although not so much as in privatised firms. In addition, the decentralisations have affected secondary parts of the production activity of state defence organisations. For this reason, their impact on the central organisation has only been residual, and in fact, a central core has remained intact in all cases. Regarding the effects on the small companies, financial, material and organisational 
support from the parent company, or the possibility of selling their production in advance (availability of distribution channels, or monopoly over the manufacture of the product), helped them to show positive results. When they considered introducing new products, however, the small size of the newly created companies posed problems. These are increasingly important in so far as the companies are unable to generate initial investment or develop sub-sections to carry our marketing or commercial activities.

In the future, the growth of decentralisation in stable state organisations is anticipated owing to the absence of state funds and the deterioration of the economic situation of these entities. However, we must point out that the specialisation of the defence organisations which remain in state ownership is conditioned by the requirements of arms production, which makes internal decentralisation difficult from a technical point of view.

\section{Conclusion}

During the period we have studied privatisation extended to a substantial part of the Russian defence industry, and the objective established in 1993 was met. However, the results in terms of production adjustment were small. This statement is supported by the severe decline in production experienced by defence organisations in this period, although we should be careful owing to the recent nature of the phenomenon.

One important result of privatisation was that the decision-making capacity of defence company managers increased. This situation created a basis for exploring new avenues for production restructuring. Decentralisation was one of the main types of reorganisation, leading to the creation of small companies within defence organisations. In the case of organisations belonging to the state, the companies created had a substantially smaller qualitative and quantitative importance within the parent company. Privatisation stimulated the creation of small companies within large defence companies.

The main traits of decentralisation can be summarised as follows. In the defence industry, the technology used or developed is very specific: for this reason, it was not applied in the small companies. If the technology had been re-used, the financial cost of adapting it to the new lines of production would have been very high. Frequently, when funds were available, Western patents would be bought. In addition, small companies focused on research activities or production, depending on the original activities of the defence organisation. This showed that some of the companies were living on the past accumulation of the defence organisation but had serious problems in trying to renew their existing capital. That is to say, the decentralised firms capacity to survive in the medium-long term was questionable. On the other hand, even if a small company succeeded in becoming a strategic part of a defence organisation (for instance the design or research centre), the future of the defence organisation itself was also in question.

A similar situation is observed with equipment and machinery. On the one hand, moving them to the small companies implied a potential reduction in the production capacity of the defence organisation, as well as the introduction or consolidation of breaches in the production process. On the other hand, if new machinery or equipment 
needed to be bought, financing them was difficult, since a new small company needed instant capital, but its small size prevented it from raising the funds required for the critical minimum investment. This situation lead to the creation of small companies with a purely formal or latent existence.

The major element in decentralisation may be labour, although this aspect should also be considered with caution. First, the application of a decentralisation policy within a defence organisation implies the privatisation of its labour, with subsequent (maybe potential) negative effects on production. This situation affects the productive and technological potential of the organisation. Nevertheless, the use of labour in the company implies the development of new tasks as well as the creation of new organisational arrangements. The immediate result is the loss of skilled employees and, subsequently, the deterioration of one of the factors considered more positive in the defence industry. In addition, serious doubts arose regarding the capacity of the employees to carry out the new tasks. An example is the necessity to stimulate cost reduction or the production of products which do not have an equivalent in the West.

The decentralised companies use the premises of the defence organisations. In quantitative terms, this is not a problem, because of the space surplus which they had and the fall in production, which liberated additional room. However, in qualitative terms, the situation changes substantially. In other words, companies may have to adapt to the new space even though it is not ideal for the development of a new production activity. This situation hinders the reduction of costs, thus reducing the efficiency of the newly created companies.

One of the main problems the companies have to face is the development of distribution channels and gaining access to commercial structures. This is due to two reasons. Firstly, it is not possible to use the traditional channels of the defence organisation either because they no longer exist or because they were used for totally different products. Secondly, the new companies focus on scientific or production activities but do not work on the sales of the products. These deficiencies isolate the scientific or industrial activities from demand and constitute an essential factor in explaining the inefficiency of their economic activities. In particular, products are designed or manufactured which do not find a demand either because the market is saturated (due to strong competition), because there is no market (bad quality, too high prices), the demand is not met (absence of post-sale service, inability to offer warranty), or it is even undetected (lack of distribution channels to reach the markets).

We can say that the decentralisations generated in the defence industry are characterised by ineffectiveness and inefficiency due to important technical constraints (deficient technology. insufficient equipment, qualitative loss of human capital), organisational handicaps (small size, absence of a new internal management structure), and economic and commercial factors (absence of sections orientated to distribution, marketing, post-sales follow-up). The result is the inability to adapt to market demand, which makes the existence of the companies ephemeral or strictly formal. In most of the cases when a company manages to survive, it is because they have made the most of the economic conditions of the defence organisation, that is, they have taken advantage of its operational basis in a speculative way. Therefore, those decentralisations which have actually succeeded and have contributed to the production re-adjustment are in fact marginal. The decentralised companies are not 
helping to overcome either the production difficulties of the defence organisations or indeed their own.

\section{University of Valencia}

1 For the first stage of privatisation of the defence industry see A. Sánchez-Andrés, 'The First Stage of Privatisation of the Russian Military Industry'. Communist Economies \& Economic Transformation, 7, 3, 1995, pp. 353-367.

2 Ukaz O osobennostyakh privatizatsii i dopolnitel nykh merakh gosudarstvennogo regulirovaniya deyatel nosti predpriyatii oboronnykh otraslei promyshlennosti. n 1267,19 August 1993: comment in Kommersant, 1993, 34, p. 22.

Kommersant, 1994, 21, pp. 61-65.

Kommersant'-Daily. 20 May 1994, p. 8.

5 A. Sánchez-Andrés, 'The Transformation of the Russian Defence Industry'. Europe-Asia Studies, 47, 8. December 1995, pp. 1269-1292.

${ }^{6}$ Moskovskie nowosti, 1995, 39, p. 29.

Kommersant'-Daily, 1 February 1995, p. 10.

${ }^{8}$ I. Musienko, 'Management Behaviour in Siberian Defence Enterprises', in P. Opitz \& W. Pfaffenberger (eds), Adjustment Processes in Russian Defence Enterprises within the Framework of Conversion and Transition (Münster, LIT Verlag, 1994), p. 32.

${ }^{9}$ Kommersant'-Daily, 1 October 1993, p. 8.

"Rossiiskava gazeta, 20 April 1996, p. 1.

11 Kommersant'-Daily, 1 October 1993, p. 8.

$12 \mathrm{O}$. Yu. Kuznetsov, 'O nekotorykh aspektakh privatizatsii predpriyatii oboronnogo kompleksa', Voprosy ekonomiki i konversii, 1995, 1, p. 10.

13 Segodnya, 4 March 1995, p. 2.

14 Kommersant'-Daily, 22 April 1995, pp. 1 and 2.

15 Ukaz 'O poryadke peredachi v 1995 godu $v$ zalog aktsii, nakhodyashchikhsya v federal'noi sobstvennosti', no. 889, 31 August 1995.

16 Segodnya, 3 November 1995 , p. 4.

17 Ponedel'nik, 1996, 2, p. 46.

18 Kommersant'-Daily, 26 December 1995, p. 2.

19 Ukaz prezidenta RF $\cdot O$ merakh po obespecheniyu effektivnosti gosudarstvennogo kontrolya za privatizatsiei predpriyatii i organizatsii oboronnogo kompleksa', no. 541, 13 April 1996 and Polozhenie 'O Federal'noi komissii pri Pravitel'stve RF po obespecheniyu kontrolya za upravleniem i privatizatsiei ob"ektov, predpriyatii organizatsii oboronnogo kompleksa”, no. 541, 13 April 1996.

20 Postanovlenie Pravitel'stva RF 'O perechne predpriyatii i organizatsii oboronnogo kompleksa privatizatsiya kotorykh zapreshchena', no. 802, 12 July 1996.

${ }^{2}$ Ukaz 'O sovershenstvovanii gosudarstvennogo upravleniya oboronnoi promyshlennost'yu', no. 686, 8 May 1996 and Postanovlenie Pravitel'stva RF 'Voprosy Ministerstva oboronnoi promyshlennosti Rossiiskoi Federatsii', no. 815, 18 July 1996.

2 Ekonomika $i$ thizn', 1993, 21, p. 1; Ekonomika i hizn' (Vash partner), 1993, 51, p. 16 and according to C. G. Gaddy, The Price of the Past. Russia's Struggle with the Legacy of a Militarized Economy (Washington, DC. The Brookings Institution, 1996), pp. 193-194, the total number of defence organisations comes to 1656. 1. p. 3.

${ }^{23}$ Yu. P. Zhdanov, 'Regional'nye aspekty konversii v Rossiiskoi Federatsii'. Konlersiya, 1996,

${ }_{25}$ Moskovkie novosti, 1995, 39, p. 29 and Krasnaya zvezda, 20 July 1996, p. 1.

25 This statement is drawn from the comparison between the actual results and the forecast in Ekonomika i zhizn'(Vash partner), 1993, 51, p. 16. In particular, while in 1994 the percentage of privatised companies was thought to be $29-38 \%$ of the total, the actual percentage was $44 \%$. In 1995 . privatisation should have affected $41-47 \%$ of the defence industry, whereas as a matter of fact the actual percentage was $70 \%$.

26 Own elaboration with data from Tsentr Ekonomicheskoi kon"yunktury, Rossiya-1994. Ekonomicheskava kon"vunktura (Moscow, September 1994), p. 133; Tsentr Ekonomicheskoi kon"yunktury, Rossiva-1996. Ekonomicheskaya kon"yunktura (Moscow, September, 1996), p. 97; Tsentr Ekonomicheskoi kon"yunktury, Rossiva-1997. Ekonomicheskaya kon"yunktura (Moscow, March 1997), p. 107.

27 P. Opitz \& W. Pfaffenberger 'Transformation and Industrial Structure in Russia', in Opitz \& Pfaffenberger (eds), p. 18; and T. Cronberg, 'Enterprises' Strategies to Cope with Reduced Defence 
Spending-The Experience of the Perm Region', in M. McFaul \& T. Perlmutter (eds), Privatization, Conversion. Enterprise Reform in Russia (Boulder, Westview Press, 1995), p. 195.

28 Ekonomika i hizn', 1993, 37, p. 18.

29 Sánchez-Andrés, 'The Transformation ...', pp. 1275-1276.

30 Ekspert, 1996, 13, p. 20.

31 Sánchez-Andrés, 'The Transformation ...', p. 1275.

32 RIKA, 1994, 8, p. 3; and Le Courrier des Pays de l'Est, 414, 1996, p. 43.

33 Le Courrier des Pays de l'Est, 414, 1996, p. 57.

34 RIKA, 1994, 7, p. 4.

35. Moskovskie novosti, 1993,35, p. 7.

36 Inzhenernaya. gazeta. 1995, 44, p. 2; Kommersant'-Daily, 19 August 1995, p. 11 and Kommersant'-Daily, 17 October 1995, p. 9

37 RIKA, 1995, 29, p. 5-7.

38 B. Rakitin, "Samolety marki "Su", Konversiva v mashinostroenii, 1995, 3, p. 32-35.

39 Konversiya, 1992, 12, p. 21 and 23.

4) Although their activities were not so linked to the main activity of the defence organisation, there are other examples: KB Gyuis (Rybinsk, Yaroslavl' oblast'), where AO Tema was created with the objective of producing and selling electric and gas ovens; in the organisation Angstrem (Zelenograd, Moscow oblast'), Ankad was set up to provide computer advice; and in NPO Tekhnomash (Moscow), the company Russ was created for the manufacture of solar energy systems.

${ }^{+1}$ Konversiva v mashinostroenii, 1995, 3, p. 59 and Finansovye izvestiya, 28 March 1996, p. 2.

42 E. Denezhkina, 'Nekotorye problemy ekonomiki konversii rossiiskoi oboronnoi promyshlen-

nosti i protivorechiya ee sistemy upravleniya', Konversiya v mashinostroenii, 1996, 2, p. 45.

43 Ekspert, 1996, 22, p. 14.

4 RIKA, 1993, 43, pp. 2-3 and S. Gubanov, 'Sokhranyaem naukoemkii profil', Ekonomist, 1996, 2, pp. 62-70.

is I. V. Dzyubenko, 'Konversiya v sverdlovskoi oblasti'. EKO, 1995, 10, p. 90.

t6 Irestiva, 2 February 1994, p. 1 and Le Courrier des Pays de l'Est, 414, 1996, p. 40.

${ }^{47}$ Interviews with several employees from small companies belonging to NPO Vektor, $21-22$ May 1996, Ekaterinburg.

48 In-henernava gazeta, 1996, 21, p. 2.

49 Krasnava Ziezda, 27 May 1995, p. 6 and 15 July 1995, p. 6.

50 Interview with I. Fakhrutkinov, former director of the institute, Kazan", 28 May 1997.

51 Delovoi ural', 1992, 11, p. 1 and 3 and Le Courrier des Pays de I'Est, 414, 1996, p. 58.

52 RIKA, 1995, 5, p. 3; Inzhenernaya gazeta, 1995, 58, p. 2 and Krasnava zezda, 27 May 1995, p. 4.

53. Le Courrier des Pays de l'Est, 414, 1996, p. 56.

54 lbid, p. 48.

55 Rossiiskie vesti, 15 June 1995, p. 3.

56 Interview with V. Rassadin, Economic Forecasting Institute, 30 May 1997, Moscow.

57 Kommersant' -Daily, 29 September 1995, p. 14.

58 Ekspert, 1995, O, pp. 16-20 and Kommersant -Daily, 13 October 1995, p. 5.

59 RIKA. 1994, 38, p. 8.

66) The following companies are included in the new branch union: GP NPO Orion, GNII tochnogo elektronnogo priborostroeniya, G unitarnogo NPP Oplo, GP Eksperimental'noe konstruktorsko-tekhnologicheskoe byuro Metron, GP Elidap and GP SKB tekhniki nochnogo videniya. See Rossiiskava gazeta, 15 November 1995, p. 5.

61 Panorama Privatizatsiva, 1994, 22, p. 52 and L. Bzhilyanskaya, 'Innovatsionnaya deyatel'nost': tendentsii razvitiya i mery gosudarstvennogo regulirovaniya', Ekonomist, 1996, 3. p. 25.

62 In-henemaya gazeta, 1995, 50, p. 1 and Inzhenernaya gazeta, 1996, 4, p. 2.

6.3 RIKA, 1995, 2, pp. 6-8 and A. V. Ishutin, Ekonomika goroda: Problemy strukturnykh izmenenii', in AA. VV., Sotsial'no-ekonomicheskie problemy struktumoi perestroiki staropromyshlennogo regiona (Ekaterinburg, Institut Ekonomiki UrO RAN, 1996), p. 72.

of Rossiiskava gazeta, 13 February 1996, p. 2.

65 Nezavizimana gazeta, 27 December 1996, p. 6. 